\title{
Investigation of the Relationship between Prospective Teachers' Participative Assessment Beliefs and Individual Innovativeness State
}

\author{
Dr. Sedef SÜER* \\ Dicle University, Ziya Gökalp Education Faculty, Department of Educational Sciences, \\ Diyarbakır / Turkey, sedefsuer@gmail.com, ORCID: 0000-0002-1833-9286 \\ Doç. Dr. İsmail KİNAY \\ Dicle University, Ziya Gökalp Education Faculty, Department of Educational Sciences, \\ Diyarbakır / Turkey, ismailkinay84@gmail.com, ORCID: 0000-0001-8963-8411
}

\begin{abstract}
This study aimed to examine the relationship between prospective teachers' participative assessment beliefs and individual innovativeness state. The correlational survey method was used in this study and the study group was comprised of 313 senior students studying in faculty of education. The data of the study were collected via "Beliefs About Participative Assessment Instrument" and "Individual Innovativeness Scale". The data obtained were analyzed through Statistical Package for the Social Sciences (SPSS). The results of the analysis showed that prospective teachers have a high level of participative assessment beliefs while their individual innovativeness state was determined to be in the category of interrogators. In addition, a positive relationship was found between prospective teachers' participative assessment beliefs and their individual innovativeness state. Finally, prospective teachers' participative assessment beliefs were found to be a significant predictor of their individual innovativeness state.
\end{abstract}

* Sorumlu Yazar. Tel: +90 (553) 4555479

Makale Tarih Bilgisi. Gönderim: 02.01.2020, Kabûl: 11.04.2020, Basım: Haziran, 2021.

(C) 2021. Kalem Eğitim ve Sağlık Hizmetleri Vakfı. Bütün Hakları Saklıdır. ISSN: 2146-5606, e-ISSN: 2687-6574. 
Anahtar Kelimeler: Beliefs; Individual innovativeness; Participative assessment; Prospective teachers; $21^{\text {st }}$ century skills.

\title{
Öğretmen Adaylarının Katılımcı Değerlendirmeye Yönelik İnançları ile Bireysel Yenilikçilik Düzeyleri Arasındaki İlişkinin İncelenmesi
}

\begin{abstract}
$\ddot{O} z$
$\mathrm{Bu}$ çalışmada öğretmen adaylarının katılımcı değerlendirmeye yönelik inançları ile bireysel yenilikçilik düzeyleri arasındaki ilişki incelenmeye çalışılmıştır. Araştırmada ilişkisel tarama modeli kullanılmış olup çalışma grubunu 2018-2019 eğitim öğretim yılında bir devlet üniversitesinin eğitim fakültesine kayıtlı 313 öğretmen adayı oluşturmaktadır. Araştırma verileri "Katılımcı Değerlendirmeye Yönelik İnanç Ölçeği”" ve "Bireysel Yenilikçilik Ölçeği”" ile toplanmıştır. Araştırmada elde edilen veriler SPSS paket programı kullanılarak analiz edilmiş ve verilerin analizinde yüzde, frekans, korelasyon ve basit regresyon analiz yöntemleri kullanılmıştır. Yapılan analizler neticesinde öğretmen adaylarının katılımcı değerlendirmeye yönelik inançlarının yüksek düzeyde, yenilikçilik düzeylerinin ise sorgulayıcı kategorisinde olduğu belirlenmiştir. Ayrıca öğretmen adaylarının katılımcı değerlendirmeye yönelik inançları ile yenilikçilik düzeyleri arasında pozitif yönlü orta düzeyde ilişki olduğu, öğretmen adaylarının katılımcı değerlendirmeye yönelik inançlarının yenilikçilik düzeylerinin anlamlı yordayıcısı olduğu sonucuna ulaşılmıştır.
\end{abstract}

Keywords: İnançlar; Bireysel yenilikçilik; Katılımcı değerlendirme; Öğretmen adayları; 21. yüzyıl becerileri.

\section{Introduction}

In today's world, many countries are evolving towards an innovative education. Current educational institutions are highly criticized for failing to educate the students in a way that can satisfy the needs of the $21^{\text {st }}$ century world, which brings up the issue of how to train individuals with the required competencies to survive in $21^{\text {st }}$ century. One of the solutions put forward highlights the fact that educational institutions need to ensure the development of certain skills for the students in order to raise a generation that can stand on its own in $21^{\text {st }}$ century world.

Large scale researches has been carried out to determine the skills 
deemed necessary for students in $21^{\text {st }}$ century. These studies emphasize the development of such competencies as creativity, innovation, communication, collaboration, literacy of knowledge, critical thinking, problem-solving and decision making, digital citizenship, and the technology literacy (International Society for Technology in Education [ISTE], 2016; Partnership for $21^{\text {st }}$ Century Skills, 2010) in order for students to be successful in $21^{\text {st }}$ century. It is understood that these large scale studies encourage state-owned educational institutions to use innovative teaching models and gain innovative skills within the scope of student-centered learning in order to support innovation and provide necessary labor and equipment (Patrick and Gentz, 2016). In this context, in a global economy a process of innovation and innovativeness in cooperation with education is regarded as the key point of today's world (Stukalenko, Zhakhina, Kukubaeva, Smagulova and Kazhibaeva, 2016).

Innovativeness has been the prominent issue in the world since the 1900s. The first systematic work in this field was Diffusion of Innovation Theory (Redding, Twyman and Murphy, 2013) which was developed with the help of a French sociologists Gabriel Tarde (1903), Ryan and Gross (1943) and Everett-Rogers $(1964,1981)$ (Kaminski, 2011). According to this theory, innovativeness is defined as how early an individual adopts a novelty or idea when compared to other segments of the society and individuals are categorized into five groups according to their response to innovation: innovators, early adopters, early majority, late majority and laggards (Rogers, 2002). Hurt, Joseph and Cook (1977) defined innovativeness as willingness to change, normally distributed personally structure in society. When it comes to the $21^{\text {st }}$ century, innovativeness is handled as a skill to be developed in students, teachers and administrators via educational institutions. Innovativeness in the context of education is defined as the use of an innovation either discovered or invented as an idea, method or material in an educational setting with the aim of achieving educational goals or solving educational problems (Rusdiana, 2014). In this case, schools are considered as systems where innovations are spread and implemented rapidly (Fullan, 2007) and innovative applications are required to be emphasized in learning, teaching, measurement, assessment and working conditions (Semmel, 2009).

In an innovatively designed teaching and learning process, the teachers are expected to know and use the strategies, approaches that facilitate and accelerate learning in the teaching of a concept or subject (Sengupta and Tyagi, 
2016). Learning is considered as a social experience instead of a process that students go through alone, and the discussions, collaborations, group and discussion games are said to play an important role in this process (Wilson and Peterson, 2006). In this respect, along with developments in teaching and learning process, assessment methods also need to be consistent with the pedagogy applied in the classroom as it is a necessity for both teachers and students to evaluate the applied pedagogy in accordance with the current developments (Brew, Riley and Walta, 2009). Brown, Bull and Pendlebury (1997) articulated the expression of "If you want to change the learning of students, change the assessment methods" to emphasize that the approaches adopted in the assessment process are the cornerstone of the learning and teaching process. Reynolds and Trehan (2000) stated that the assessment method applied in the classroom should be consistent with the adopted pedagogy and teaching method as the assessment has an influence on a variety of situations, from educational practices to the teacher and student relationship, from decisions made on the individual's future career to the evaluation of the students' worth by themselves or by others. Based on these views, it is a necessity for today's society to use assessment methods consistent with an innovative pedagogy.

Considering the philosophy of education adopted, innovative human profile and the effects of assessment methods on students' development, the use of a measurement and assessment process enabling students to actively participate in an assessment towards them are highly recommended (Tan, 2004). Participative assessment, a prominent assessment method in this context, is a reflective assessment process in which students assess their work in the course using a predetermined set of criteria and provide comments for improvement (Rodríguez-Gómez, Quesada-Serra and Ibarra-Sáiz, 2016). In participative assessment, teachers and students share the responsibility of evaluating student assignments which leads students to have the opportunity to intervene in setting assessment criteria (Reynold and Trehan, 2000). Participative assessment allows for a better qualified assessment of students by providing more valid, reliable, objective and detailed data collection than the traditional ones (Sinclair, 2005). When participative assessment is used, students have a better understanding of the learning subject since the assessment process provides instant feedback to students and, the students involved in this process show more reliable, independent and reflective characteristics (Brew and Riley, 2011). Thus, students develop positive beliefs towards the necessity of assessment to contribute to their own learning (Brown and Hirschfeld, 
2008).

Positive beliefs about participative assessment may affect students' innovativeness state as individual innovativeness are expressed to be affected by such qualities as knowledge, skills, creativity and creating novel ideas (Bommer and Jalajas, 2002; Rawabdeh and Strong, 2003; Spreitzer, Sutcliffe, Dutton, Sonenshein and Grant, 2005). The related literature stated that individual innovativenes has a positive relationship with such cognitive processes as critical thinking, attitude towards learning and need for cognition (Kaya and Göçen, 2014; Özgür, 2013; Süer and Kinay, 2019). In this respect, The Ministry of National Education [MoNE] revised the curricula of educational institutions to train students with $21^{\text {st }}$ century skills such as using and producing knowledge functionally, problem solving, critical thinking, entrepreneurship, collaboration and communication and so on (MoNE, 2018). Higher Education Council [HEC] also revised the teacher training institutions' programs in line with the scientific studies and developments in related field, and $21^{\text {st }}$ century skills and competences (HEC, 2018). Based on these initiatives, both educational institutions and teacher training programs try hard to keep up with the $21^{\text {st }}$ century requirements. On the other hand, although many educational institutions design modern and innovative educational programs, they cannot abandon traditional practices while training their students and prospective teachers (Shantz, 2005), which leads to major problems in achieving educational aims and goals. At this point, teaching and learning activities contributing the development of skills and competences desired for prospective teachers need to be proven with the help of scientific studies so that the results of these can be reflected to teacher training programs and schools.

The scientific studies in the field of innovativeness mostly focus on determining the individual innovativeness state of teachers or prospective teachers (Akdeniz and Kadı, 2016; Kaya, 2017; Kocasaraç, 2018; Köroğlu, 2014) and according to these studies prospective teachers' individual innovativeness state was found to be mostly in Interrogator category which means prospective teachers try to be attentive about the innovations. In these studies and above mentioned large scale studies although prospective teachers' individual innovativeness state was stated to be enhanced in educational context, these scientific studies fail to provide necessary information on what ways and how teachers and prospective teachers can improve their own and their students' individual innovativeness state. As a matter of fact innovativeness in 
educational context highlights on a broad sense the use of educational reforms aiming to change both the goals and practices of education (Nessipbayeva, 2012). So the innovativeness can be improved with the help of using or adapting alternative methods of teaching and learning in schools (Salmon, 2005). As an alternative way of measurement and assessment participative assessment methods and techniques used in classroom are thought to contribute to innovativeness of both teachers and prospective teachers. Because pedagogical experiences of prospective teachers can be transferred and passed on to others, as well as reproduced in training techniques and methods so as to be used in their later teaching years (Nessipbayeva, 2012). At this point the results obtained in this study are expected to provide scientific background in literature and practical ideas to both teachers and teacher trainers.

\section{Aim of the Study}

This study aims to investigate the relationship between $4^{\text {th }}$ year prospective teachers' participative assessment beliefs and their individual innovativeness state. In line with this general aim, following research questions were explored:

1. What are the levels of prospective teachers' participative assessment beliefs and their individual innovativeness state?

2. What kind of distribution does exist in prospective teachers' individual innovativeness state?

3. What kind of relationship is there between prospective teachers' participative assessment beliefs and their individual innovativeness state?

4. Do the prospective teachers' participative assessment beliefs significantly predict their individual innovativeness state?

\section{Method}

\section{Research Design}

This study investigating the relationship between the prospective teachers' participative assessment beliefs and their individual innovativeness state was conducted on the basis of correlational survey method. Correlational study design is a scientific method used to determine relationships between more than two variables to obtain cause and effect relations (Büyüköztürk, Kılıç-Çakmak, Akgün, Karadeniz and Demirel, 2013).

\section{Research Sample}

The population of this study was comprised of senior college students' 
studying in one of the education faculty of a state university in the 2018-2019 academic year. The sample of the study was selected randomly from the population and was comprised of totally 313 senior students'. The distribution of the sample based on the department was presented in Table 1.

Table 1. The Distribution of the Prospective Teachers Participated in Study Based on the Department

\begin{tabular}{llll}
\hline & N & \% \\
\hline & Pre-school Teachers & 85 & 27.2 \\
& Classroom Teachers & 30 & 9.6 \\
& Turkish Language Teachers & 46 & 14.7 \\
& English Language Teachers & 26 & 8.3 \\
Departments & Art Teachers & 15 & 4.8 \\
& Social Science Teachers & 26 & 8.3 \\
& Science Teachers & 51 & 16.3 \\
& Primary School Math Teachers & 5 & 1.6 \\
& German Language Teachers & 29 & 9.2 \\
\hline Total & & 313 & 100.0 \\
\hline
\end{tabular}

\section{Research Instruments and Procedures}

"Beliefs About Participative Assessment Instrument" and "Individual Innovativeness Scale" were used as data collection instruments in this study. The instruments were handed out randomly. 318 filled questionnaires were obtained and examined, and five of them were excluded due to inaccuracy or incorrectness. Then data obtained from 313 questionnaires were recorded in the SPSS program.

\section{Beliefs about Participative Assessment Instrument (BAPAI)}

"Beliefs about Participative Assessment Instrument" is a 6-point Likerttype scale developed by Brew and Riley (2011) to measure prospective teachers' beliefs about peer assessment, discussion-oriented classroom, self-assessment and group assessment. Adopted to Turkish by İlhan, Çetin and Bars (2013) 5-point likert-type scale "Beliefs about Participative Assessment Instrument" is comprised of 20 items and four dimensions. The first dimension called beliefs about peer assessment consists nine items, second dimension called beliefs about discussion-oriented classroom consists four items, third dimension called beliefs about self-assessment consists four items and forth dimension called beliefs about group assessment consists three items. In the adaptation study of the scale to Turkish Language, the instrument confirmed with a four-factor structure parallel to the original form. Cronbach Alpha and test-retest reliability coefficients were calculated as .76 and composite reliability coefficient was calculated as .79. As a result of item analysis in 
adaptation study, corrected item total correlations were found to range from .23 to .75 . The differences between the means of the $27 \%$ upper and lower groups were determined to be significant for all items in the scale. High scores obtained from the whole scale indicate high beliefs about participative assessment (İlhan, Çetin and Bars, 2013). In our study, Cronbach Alpha reliability coefficients of BAPAI were calculated as .81 .

\section{Individual Innovativeness Scale (IIS)}

IIS was developed by Hurt, Joseph and Cook (1977) to determine individuals' innovativeness level. The scale is comprised of four dimensions and 20 items twelve of which are positive and eight are negative. IIS was adapted to Turkish Language by K1lıçer and Odabaşı (2010) and in the adaptation study, the internal consistency coefficient of the whole scale was calculated as .82, while the test-retest reliability coefficient was calculated as .87 (K1liçer and Odabaş1, 2010). In this study, Cronbach Alpha reliability coefficients of IIS were calculated as .74.

\section{Data Analysis}

The data in this research were analyzed through the SPSS program. The mean and standard deviation values were calculated to determine the level of prospective teachers' beliefs about participative assessment. The mean values regarding beliefs about participative assessment were interpreted on the basis of the score ranges and levels shown in Table 2.

Table 2. Score Ranges and Levels Used to Interpret Mean Values for Beliefs about Participative Assessment Scale

\begin{tabular}{ll}
\hline Score Ranges & Levels \\
\hline $1.00-1.80$ & Very Low (Strongly Disagree) \\
$1.81-2.60$ & Low (Disagree) \\
$2.61-3.40$ & Medium (Partly Agree) \\
$3.41-4.20$ & High (Agree) \\
$4.21-5.00$ & Very High (Strongly Agree) \\
\hline
\end{tabular}

For the scoring of the Individual Innovativeness Scale as a whole, the scoring system of "Individual Innovativeness Score $=42+$ (total scores of the positive items)-(total scores of the negative items)" suggested by Kiliçer and Odabaş1 (2010) was used. In this regard, if the score taken from the scale is 80 or above, then the person is accepted as "innovator"; if it is between 69 and 80 , then the person is accepted as "pioneer"; if it is between 57 and 68, then the person is accepted as "interrogator"; if it is between 46 and 56, then the 
person is accepted as "skeptic" and if it is 46 or below, then the person is accepted as "traditionalist" (Kılıçer and Odabaşı, 2010; http://www.jamescmccroskey.com/measures/ innovation.htm).

Percentages and frequencies of the prospective teachers in each category were calculated to determine how the individual innovativeness categories of prospective teachers are distributed. For the third research question, correlation coefficients and for the fourth research question of the study simple linear regression analysis were used. According to Büyüköztürk (2011) if the calculated correlation coefficient is between .70-1.00 it is interpreted to have a high correlation if it is between .30-.70 then interpreted to have a medium correlation and if it is between .00-.30 then interpreted to have a low correlation. The significance degree in the analysis was tested at .05 level.

Can (2013) suggested that in order to use simple linear regression analysis at least two variables need to be tested with equivalent scores. Of these two variables, generally, one is called predictor and the other is predicted, and they both should show normal distribution and a linear relationship. In line with this, in this study the scores obtained from the predictor variable (participative assessment beliefs) and the predicted variable (individual innovativeness) initially were tested in terms of normal distribution thus KolmogorovSmirnov test was used and the results obtained from the test were found to be $p=.200>.05$ for participative assessment beliefs and $p=.062>.05$ for individual innovativeness. Along with this, in order to test predictor variable (participative assessment beliefs) and the predicted variable (individual innovativeness) in terms of normal distribution skewness values were examined. According to Büyüköztürk (2011), if the coefficient of skewness is within the ranges of +1 and -1 , it can be interpreted that the scores do not show a significant deviation from the normal distribution. The analysis of the study showed that skewness coefficients of predictor and predicted variables were .079 and .572 , respectively. Therefore, it could be suggested that the data shows normal distribution for both predictor and predicted variables. To determine whether there is a linear relationship between the predictor and the predicted variables, the scatter diagram is visually checked (Can, 2013). In this study, the scattering diagram was examined visually and a linear relationship was observed between the predictor and the predicted variables. In conclusion, the scores of these two variables were determined to be suitable for performing simple linear regression analysis. 


\section{Findings}

The findings obtained through this study were presented in line with research questions.

\section{Findings Regarding the First Research Question}

The levels of prospective teachers' participative assessment beliefs and their individual innovativeness state were determined by calculating mean and standard deviation values. Findings regarding the levels of prospective teachers' participative assessment beliefs and their individual innovativeness state were presented in Table 3.

Table 3. Mean and Standard Deviation Values Regarding Prospective Teachers' Participative Assessment Beliefs and Their Individual Innovativeness State

\begin{tabular}{lcccc}
\hline & f & $\overline{\boldsymbol{x}}$ & SD & Level \\
\hline Perticipative Assessment Beliefs & 313 & 3.51 & .51 & High \\
Individual Innovativeness & 313 & 66.89 & 10.77 & Interrogator \\
\hline
\end{tabular}

When Table 3 was examined, it was seen that prospective teachers' participative assessment beliefs is high which indicates that prospective teachers have a strong beliefs about participative assessment techniques. As for the individual innovativeness level, prospective teachers were determined to be in the Interrogator category. That means the prospective teachers are not totally innovative but attentive about innovations.

\section{Findings Regarding the Second Research Question}

Percentages and frequencies in each innovativeness category were calculated in order to determine what kind of a distribution exists in prospective teachers' individual innovativeness state and the related findings were presented in Table 4.

Table 4. Distribution of Prospective Teachers in terms of Individual Innovativeness State

\begin{tabular}{lcc}
\hline Categories & n & \% \\
\hline Traditional & 10 & 3.2 \\
Skeptic & 37 & 11.8 \\
Interrogator & 128 & 40.9 \\
Pioneer & 104 & 33.2 \\
Innovator & 34 & 10.9 \\
\hline
\end{tabular}

As seen in Table 4, the prospective teachers' individual innovativeness state was determined to be mostly in the interrogator category $(40.9 \%)$ and 
then in pioneer category (33.2\%), and at least in the traditionalist category $(3.2 \%)$. This finding indicates that nearly $70 \%$ of the prospective teachers either open to innovations or cautious about innovations.

\section{Findings Regarding the Third Research Question}

Partial correlation analysis was used to determine the relationship between prospective teachers' participative assessment beliefs and individual innovativeness state and the related findings were presented in Table 5.

Table 5. The Findings of the Correlation Analysis Regarding the Relationship between Prospective Teachers' Participative Assessment Beliefs and Individual Innovativeness State

\begin{tabular}{lc}
\hline & Participative Assessment Beliefs \\
\hline Individual Innovativeness & $.476^{*}$ \\
\hline$* p<.05$ &
\end{tabular}

As seen in Table 5, a positive and moderate level of significant relationship was observed between prospective teachers' participative assessment beliefs and individual innovativeness state. This finding indicates that as the prospective teachers' participative assessment beliefs enhances their innovativeness level also enhances and vice versa.

\section{Findings Regarding the Forth Research Question}

Simple linear regression analysis was used to determine whether prospective teachers' participative assessment beliefs significantly predicted their individual innovativeness state and the related findings were presented in Table 6 .

Table 6. The Findings of the Simple Linear Regression Analysis on the Prediction of Individual Innovativeness State of Prospective Teachers

\begin{tabular}{llllll}
\hline Variable & B & Standard Error & $\boldsymbol{\beta}$ & $\mathbf{t}$ & $\boldsymbol{p}$ \\
\hline Fixed Participative & 31.373 & 3.758 & .476 & 8.349 & .000 \\
Assessment Beliefs & 10.119 & 1.060 & & 9.549 & .000 \\
\hline $\mathrm{R}=.476, \mathrm{R}^{2}=.224, \mathrm{~F}=91.191, p=.00$ & & & &
\end{tabular}

Table 6 showed that prospective teachers' participative assessment beliefs are a significant predictor of their individual innovativeness state. Besides, about $22 \%$ of the variance regarding the individual innovativeness state of prospective teachers was accounted for by their participative assessment beliefs. Based on this finding the prospective teachers' participative assessment beliefs could be said to be an important factor of innovativeness level. 


\section{Discussion}

In this study, investigating the relationship between prospective teachers' participative assessment beliefs and the individual innovativeness state, prospective teachers' participative assessment beliefs were determined to be high which may result from the fact that prospective teachers have been brought up with an constructivist pedagogy in educational institutions thus they have constructivist understanding of how the knowledge is constructed. According to constructivist pedagogy, learning is considered as social process rather than an individual one. Individuals actively constructs knowledge rather than passively receiving it from the environment (Liu and Chen, 2010). In constructivist classrooms, the learning process is handled as a cycle of questioning, interpreting and analyzing information, integrating knowledge and thinking, and integrating new knowledge with previous learning experiences (Marlowe and Page 2005). Therefore, social discussion environments, group and peer studies play a key role in the learning process (Wilson and Peterson, 2006). As the constructivist pedagogy requires the students actively take part in their own assessment and measurement by reflecting on their own learning process (Collins, 1990), the use of different methods such as self-assessment which enables the student to actively participate in the assessment process is highly recommended (Yurdabakan, 2011). From this point of view, constructivist approach emphasizes the use of student centered learning and assessment methods that enable students to actively participate in the process which in turn leads to prospective teachers' participative assessment beliefs to be high. Besides, the use of participative assessment methods has some advantages for the learners. Participative assessment methods provide prospective teachers the opportunity to learn their peers' views about their work and learning process in higher education institutions as well as helping them to understand the relativity of constructing the knowledge (Baxter-Magolda, 1992; Perry, 1970). In addition, the use of participative assessment methods eliminates both the evaluation process from being a mystery (Brindley and Scoffield, 1998) and subjectivity of teacher assessment (Brown and Hirschfeld, 2008). Considering both the adopted constructivist approach and the advantages of participative assessment, it is seen that prospective teachers prefer to use assessment methods such as self-assessment, peer assessment and group assessment, which enable students to actively take part and express their opinion (Andresen, Jackson and Kirby, 1994; Bloxham and West, 2004; Sambell, McDowell and Brown, 1997; Segers and Dochy 2001; Slater, 1996). In 
conclusion, it is thought to have a positive effect on prospective teachers' participative assessment beliefs.

The other result obtained within the scope of this study is that prospective teachers' individual innovativeness distribution is determined to be mostly in interrogator category, which is supported by the similar studies in related field (Erdoğan and Güneş, 2013; Kert and Tekdal, 2012; Korucu and Olpak, 2015; Özgür, 2013; Parlar and Cansoy, 2017; Süer and Kinay, 2019). This indicates that prospective teachers are cautious towards innovations and show slow progress (Kaminski, 2011; Kılıçer and Odabaş1, 2010). However, the 21 st century pedagogy requires teachers and prospective teachers to follow innovations, be productive, adapt to a developing and progressing information society, and follow innovative practices in education (Keleşoğlu, 2017). In order to use innovative activities in the learning and teaching environment, standard practices should be avoided and different and alternative educational activities should be designed by using the same time and resources (Redding, Twyman and Murphy, 2013). Therefore, educational institutions need to support and implement the use of innovative teaching models based on learner centered education in order to raise innovative generations (Patrick and Gentz, 2016). In this context, it may be suggested to use participative assessment method as an alternative to standard assessment approaches. Because another result obtained within the scope of this study is that a positive and moderate level of significant relationship is observed between prospective teachers' participative assessment beliefs and individual innovativeness state as well as prospective teachers' participative assessment beliefs is a significant predictor of their individual innovativeness state. In this case, it could be said that prospective teachers educated with a constructivist pedagogy have beliefs about the necessity of using methods in which they can actively take part in and take the responsibilty of their own assessment process as in the case of their learning process. In addition prospective teachers' assessment beliefs can be interpreted to contribute their individual innovativeness state as innovativeness in educational context can be achieved through student-centered practices (Alismail and Mcguire, 2015; Sofanudin, Rokhman and Rusdarti, 2016). When considered in student centered context, participative assessment provides students with a real-life assessment experiences that allows them to use such skills as thinking, analyzing and critical decision-making on self-study and group work as well as contribute to instill the idea that assessment should be done in this way. Faced with real-life problems, the students need to use such 
skills as accessing and analyzing the knowledge, critical thinking and interpersonal relationships which in turn contribute student to develop flexible, creative and innovative skills (Amar and David, 2016).

\section{Conclusion and Implications}

Within the scope of this study investigating the relationship between prospective teachers' participative assessment beliefs and the individual innovativeness state, prospective teachers' participative assessment beliefs have been determined to be high and individual innovativeness distribution is mostly in interrogator category. Additionally, a positive and moderate level of significant relationship is observed between prospective teachers' participative assessment beliefs and individual innovativeness state as well as prospective teachers' participative assessment beliefs is a significant predictor of their individual innovativeness state. Based on these results, the following implications can be put forward:

- Student-centered innovative practices (such as innovative teaching methods and innovative assessment and measurement techniques) that will enhance the individual innovativeness state of prospective teachers should be included to teacher training programs.

- In teacher training institutions, the assessment and measurement process should be designed to contribute to the students' both learning and innovative skills. Besides, the paper and pen assessment techniques, the use of alternative assessment techniques as self-assessment, peer assessment and group assessment should be encouraged in courses.

- Different studies handling certain teaching and learning practices as independent variables can be conducted to contribute prospective teachers' individual innovativeness state.

\section{References}

Akdeniz, A. and Kad1, A. (2016, December). Investigating individual innovativeness levels and lifelong learning tendencies of students in TMSC. Paper presented at the meeting of ICLEL Conferences Sakarya University Faculty of Education, Sakarya.

Alismail, H. A. and McGuire, P. (2015). $21^{\text {st }}$ century standards and curriculum: current research and practice. Journal of Education and Practice, 6(6), 150-154.

Amar, S. and David, N. B. (2016). Realistic intelligence and $21^{\text {st }}$ century skills in adapted learning environment. American Journal of Educational Research, 4(8), 588-596.

Andresen, L., Jackson, M. and Kirby, E. (1994). Learning by doing. Higher Education Research and Development, 13(2), 111-120. 
Baxter-Magolda, M. (1992). Knowing and reasoning in college: Gender-related patterns in students' intellectual development. San Francisco: Jossey-Bass.

Bloxham, S. and West, A. (2004). Understanding the rules of the game: Marking peer assessment as a medium for developing students' conception of assessment. Assessment and Evaluation in Higher Education, 39(6), 721-733.

Bommer, M. and Jalajas, D. (2002). The innovation work environment of high-tech SMEs in the USA and Canada. R\&D Management, 32(5), 379-386.

Brew, C. and Riley, P. (2011). Measuring student support for participative assessment and related strategies: Development and testing of the beliefs about participative assessment instruments (BAPAI). Australian Journal of Teacher Education, 36(4), 32-52.

Brew, C., Riley, P. and Walta, C. (2009). Education students and their teachers: comparing views on participative assessment practices. Assessment \& Evaluation in Higher Education, 34(6), 641-657.

Brindley, C. and Scoffield, S. (1998). Peer assessment in undergraduate programs. Teaching in Higher Education, 3(1), 79-89.

Brown, G., Bull, J. and Pendlebury, M. (1997). Assessing student learning in higher education. London: Routledge.

Brown, G. T. L. and Hirschfeld, G. H. F. (2008). Students' conceptions of assessment: Links to outcomes. Assessment in Education: Principles, Policy \& Practice, 15(1), 3-17.

Büyüköztürk, Ş. (2011). Sosyal bilimler için veri analizi el kitabı (15. baskı). Ankara: Pegem Akademi.

Büyüköztürk, Ş., Kılıç-Çakmak, E. K., Akgün, Ö. E., Karadeniz Ş. and Demirel, F. (2013). Bilimsel araştırma yöntemleri. Ankara: Pegem Akademi Yayınları.

Can, A. (2013). SPSS ile bilimsel araştırma sürecinde nicel veri analizi. Ankara: Pegem Akademi.

Collins, A. (1990). The role of computer technology in restructuring schools. Restructuring for Learning with Technology. Retrieved from http://citeseerx.ist.psu.edu

Erdoğan, D. G. and Güneş, D. Z. (2013). The relationship between individual innovatiness and change readiness conditions of students attending faculty of education. Procedia-Social and Behavioral Sciences, 106, 3033-3040. doi: 10.1016/j.sbspro.2013.12.349

Fullan, M. (2007). The new meaning of educational change. London: Routledge Falmer.

Hurt, H. T., Joseph, K. and Cook, C. D. (1977). Scales for the measurement of innovativeness. Human Communication Research, 4, 58-65.

ISTE. (2016). ISTE Standards for Educators/Students. Retrived from http://www.iste.org

İlhan, M., Çetin, B. and Bars, M. (2013). Katılımcı Değerlendirmeye Yönelik İnanç Ölçeği'nin (KDYIÖ) Türkçe uyarlaması: geçerlik ve güvenirlik çalışması. Journal of European Education, 3(2), 17-35.

Kaminski, J. (2011). Diffusion of innovation theory. Canadian Journal of Nursing Informatics, 6(2), 1-7.

Kaya, A. and Göçen, A. (2014). Öğretmen adaylarının bireysel yenilikçilik özellikleri ile öğrenmeye ilişkin tutum düzeyleri. Milli Eğitim Dergisi, 44(204), 135-154. 
Kaya, S. (2017). Biyoloji öğretmenlerinin bireysel yenilikçilik düzeylerinin incelenmesi. Unpublished master's thesis, Dicle University Institute of Education.

Keleşoğlu, S. (2017). Öğretmen eğitiminde yaratıcı düşünme ve inovasyon eğitim programının tasarımı, denenmesi ve değerlendirilmesi. Unpublished doctoral disseration, Gazi University Institute of Education.

Kert, S. B. and Tekdal, M. (2012). Comparison of individual innovativeness perception of students attending different education faculties. University of Gaziantep Journal of Social Sciences, 11(4), 1150-1161.

Kılıçer, K. and Odabaşı, H. F. (2010). Bireysel Yenilikçilik Ölçeği (BYÖ): Türkçeye uyarlama, geçerlik ve güvenirlik çalışması. Hacettepe Üniversitesi Ĕgitim Fakültesi Dergisi, 38, 150-164.

Kocasaraç, H. (2018). Fen ve sosyal bilimler lisesi öğretmenlerinin yenilikçilik durumlarının değerlendirilmesi. Unpublished doctoral disseration, Yıldız Teknik University Institute of Social Science.

Korucu, A. T. and Olpak, Y.Z. (2015). Examination of teacher candidates' individual innovativeness properties from the different variables. Educational Technology Theory and Practice, 5(1), 111-127.

Köroğlu, A. Y. (2014). Okul öncesi ögretmenlerinin ve ögretmen adaylarının bilişim teknolojileri özyeterlik algılarl, teknolojik araç gereç kullanım tutumları ve bireysel yenilikçilik düzeylerinin incelenmesi. Unpublished master's thesis, Gazi University Institute of Education.

Liu, C. C. and Chen, I. J. (2010). Evolution of constructivism. Contemporary Issues in Education Research, 3(4), 63-66.

Marlowe, B. A. and Page, M. L. (2005). Creating and sustaining the constructivist classroom (Rev. ed.). Thousand Oaks, CA: Corwin.

MEB. (2018). Öğretim Programları. Retrived from http://mufredat.meb.gov.tr/Programlar.aspx

Nessipbayeva, O. (2012, June). The competencies of the modern teacher. Paper presented at the Annual Meeting of the Bulgarian Comparative Education Society, Kyustendil.

Özgür, H. (2013). Bilişim teknolojileri öğretmen adaylarının eleştirel düşünme eğilimleri ile bireysel yenilikçilik özellikleri arasındaki ilişkinin çeşitli değişkenler açısından incelenmesi. Mersin Üniversitesi Eğitim Fakültesi Dergisi, 9(2), 409420.

P21. (2010). Partnership for 21st Century Skills. Retrieved from http://www.p21.org

Parlar, H. and Cansoy, R. (2017). Examining the relationship between teachers' individual innovativeness and professionalism. International Education Studies, 10(8), 1-11.

Patrick, S. and Gentz, S. (2016). Innovation zones: Creating policy flexibility for personalized learning. https://files.eric.ed.gov/fulltext/ED567870.pdf.

Perry, W. (1970). Forms of intellectual and ethical development in the college years: a scheme. New York: Holt, Rinehart \& Winston.

Rawabdeh, I. and Strong, B. (2003). Developing technical entrepreneurship in less developed countries (A case study of Jordan). UK: Brigham University Press.

Redding, S., Twyman, J. S. and Murphy, M. (2013). What is an innovation in learning. In M. Murphy, S. Redding and J. Twyman, (Eds.), Handbook on innovations in 
learning (pp. 3-14). Philadelphia, PA: Center on Innovations in Learning, Temple University; Charlotte, NC: Information Age Publishing.

Reynolds, M. and Trehan, K. (2000). Assessment: a critical perspective. Studies in Higher Education, 25(3), 267-278.

Rodríguez-Gómez, G., Quesada-Serra, V. and Ibarra-Sáiz, M. S. (2016). Learningoriented e-assessment: the effects of a training and guidance programme on lecturers' perceptions. Assessment \& Evaluation in Higher Education, 41(1), 35 52.

Rogers, E. M. (2002). Diffusion of preventive innovations. Addictive Behaviors, 27(6), 989-993.

Rusdiana, A. (2014). Konsep inovasi pendidikan. Bandung: CV Pustaka Setia.

Salmon, G. (2005). Flying not flapping: a strategic framework for eLearning and pedagogical innovation in higher education institutions. ALT-J, 13(3), 201-218.

Sambell, K., McDowell, L. and Brown, S. (1997). 'But is it fair?': An exploratory study of students perceptions of the consequential validity of assessment. Studies in Educational Evaluation, 23(4), 349-371.

Segers, M. and Dochy, F. (2001). New assessment forms in problem-based learning: The value-added of the students' perspective. Studies in Higher Education, 31(5), 327-343.

Semmel, M. L. (2009, March). Museums, libraries, and $21^{\text {st }}$ century skills. In Proceedings of Society for Information Technology \& Teacher Education International Conference, Institute of Museum and Library Services, Washington, DC.

Sengupta, A. and Tyagi, H. K. (2016). Teaching excellence and innovative practices: A case study of national awardee teachers of India. Journal of Education and Practice, 7(1), 48-53.

Shantz, D. (2005). Öğretmen eğitiminde yenilikçi bir yaklaşım mı yoksa geleneksel bir anlayış mı? Ankara Üniversitesi Ë̆itim Bilimleri Fakültesi Dergisi, 38(2), 187-195.

Sinclair, M. A. (2005). Participative assessment. In J. R. Wilson and N. Corlett, (Eds.), Evaluation of human work (pp: 83-112). USA: Taylor \& Francis Group.

Slater, T. F. (1996). Portfolio assessment strategies for grading first-year university physics students in the USA. Physics Education, 31(5), 329-333.

Sofanudin, A., Rokhman, F. and Rusdarti, W. (2016). Quality-Oriented management of educational innovation at madrasah ibtidaiyah. Journal of Education and Practice, 7(27), 176-180.

Spreitzer, G., Sutcliffe, K., Dutton, J., Sonenshein, S. and Grant, A. M. (2005). A socially embedded model of thriving at work. Organization Science, 16(5), 537 549.

Stukalenko, N. M., Zhakhina, B. B., Kukubaeva, A. K., Smagulova, N. K. and Kazhibaeva, G. K. (2016). Studying innovation technologies in modern education. International Journal of Environmental and Science Education, 11(14), 66126617.

Süer, S. and Kinay, I. (2019). Investigation of relationship between prospective teachers' need for cognition level and individual innovativeness state. International Online Journal of Educational Sciences, 11(3), 1-12.

Tan, K. H. (2004). Does student self-assessment empower or discipline students? Assessment \& Evaluation in Higher Education, 29(6), 651-662. 
Wilson, S. M. and Peterson, P. L. (2006). Theories of learning and teaching: What do they mean for educators? Retrieved from www.nea.org/books.

YÖK. (2018). Yeni Ögretmen Yetiştirme Lisans Programlart. https://www.yok.gov.tr/kurumsal/idari-birimler/egitim-ogretim-dairesi/yeniogretmen-yetistirme-lisans-programlari.

Yurdabakan, İ. (2011). The view of constructivist theory on assessment: Alternative assessment methods in education. Ankara University Journal of Faculty of Educational Sciences, 44(1), 51-77. 